\title{
marketing.
}

\section{Socio-Economic and Demographic Profile of Traditional and Functional Food Consumers in Serbia}

\author{
Žaklina Stojanović, Dominique Barjolle
}

\begin{abstract}
Consumer quantitative survey was performed on general population $18+$ in Serbia at the end of September - begging of October 2010. The instrument used in this survey was a structured questionnaire. The stratified three-staged random representative sample is applied $(\mathrm{N}=516)$. Based on reported frequency of consumption two groups of consumers were identified: (1) conservative consumers who reported high level of traditional food consumption and simultaneously lower level of functional food consumption (NT=196); (2) innovators represented by the heavy functional food consumers who reported lower level of traditional food consumption $(\mathrm{NF}=60)$. A descriptive statistical analysis (parametric and nonparametric) was conducted with the aim to investigate all statistically significant differences between two consumers' group profiles.
\end{abstract}

The so-called conservative consumers dominate over heavy functional food consumer group in our sample. The heavy traditional food consumers are older on average and more unemployed (as retired people are considered as unemployed) and exposed to social influences. "Traditional food" in Serbia is perceived as home-made, tasty and healthy, with long heritage. Differences in age and education between two compared consumers groups indicate possible transition of diet pattern toward more frequent functional food consumption.

Key words: Traditional Food, Functional Food, Consumption, Consumer Profile.

\section{INTRODUCTION}

Traditional products constitute an important element of European culture, identity and heritage, which has been recognised both at political (Communication of the European Parliament 2011) and scientific level. Traditional food is usually defined as a typical food of a certain locality. From the consumer science point of view, some of their most important characteristics are their local origin and their way of producing: homemade or on-farm (Ricketts et al., 2006; Vogt \& Kaiser, 2008; Wilson \& Fearne, 2000; Hamermesh, 2007). At the same time, the current urban diet patterns change the occasions and the frequency of consumption of the traditional food. Additionally, some consumers see traditional food as not healthy, heavy food (Amblard et al, 2011). Consequently, the functional food with novel ingredients can be seen as an opposite to the traditional food. It may be considered as a much more global food, based on the needs of the urban consumers oriented toward healthier lifestyle. Simultaneously, there is an increasing importance of health aspects in the food choices (Diplock et al 1999; Sijtsema et al. 2003, De Jong et al 2003; Niva \& Mäkelä 2005).

To try to understand better future evolution of the consumption of traditional vs. novel food, this paper aims to discuss about differences between two consumer groups based on a survey conducted in Serbia. The reasons why the specific food groups are selected are twofold. The concept of traditional food can be explained from different points of view and recognized in different forms that link tradition with food consumption. On the other hand, the concept of novel food gains in importance with rising international competition within a country strongly exposed to transition processes. It is extremely interesting to obtain the differences regarding consumer profiles. The research aims to explain the main socio-economic and demographic factors that influence on keeping tradition in the diet pattern. Simultaneously, the analysis also indicates new trends that can reshape food consumption in Serbia, as a rapidly changing transition economy.

\section{LITERATURE REVIEW}

The literature review shows extremely low scientific interest regarding traditional and novel food consumer research in Serbia. It is important to 
understand what consumers consider under the term traditional food and how do they perceive novel food concept in general. By the qualitative research (focus group discussion), five different concepts of traditional food are recognized in Serbia (Stojanović, Ognjanov \& Filipović, 2010). In Serbia, traditional food is perceived as home-made or hand-made food, opposite to industrial products/dishes. It is prepared and consumed by many different generations and locally produced/grown. Additionally, the traditional food is exclusively produced and consumed in the country, without mentioning any export potentials. Traditional food evocates strong emotions - food of childhood, food made in village by grandmother, food consumed in a family and food connected with social events. Although we did not found any quantitative analysis on consumer attitudes and behaviour toward traditional food in the country, the qualitative research could support this paper analysis with clearly sound opinion what might be considered as traditional food in Serbia. The concept of regional food is not mentioned by any participant in the focus groups discussions. However, this concept is strongly related to GI labelling policy applied in Europe.

On the other hand, Serbian market of so called novel food (mostly considered as functional food) was initiated during mid 1990`s - first in diary and than in other sectors of food industry (Stojanović, Ognjanov \& Dragutinivić-Mitrović, 2010). Generally, little attention has been paid to the market analysis of functional food. Vast majority of articles about functional food have been published in medical journals by authors that have medical affiliation or medical background (Šobajić, 2002, Miletić et al., 2008). There are several theoretical articles emphasizing health benefits coming from consumption of functional food or analyzing legal environment and regulations regarding this food type (Stanković \& Djordjević, 2002). A few papers analyze possible contribution of marketing and technology to the offer of food with $\mathrm{N} \& \mathrm{H}$ claims (Dimitrijević-Branković et al., 2002, Ristić, 2003).

Although literature review supports overall finding about lack of data on consumer behaviour towards traditional and functional food in Serbia, certain results about food choice motives are known. The most relevant factors that explain motives for food consumption in the Western Balkans (region includes Serbia) are sensory appeal, price and health. Among the least important ethical concern and weight control were found. Milošević, Žeželj, Gorton and Barjolle argue that ranking of different food choice motives yielded no significant differences between West Balkan consu- mers: the pattern of food choice motives seems to be strikingly similar in six observed countries (Slovenia, Croatia, Bosnia and Herzegovina, Serbia, Montenegro and Former Yugoslav republic Macedonia) (Miloševic et al, 2012).

Finally, the concepts of traditional and novel/functional food are new for consumers in Serbia. The Regulation on Geographical Indications of Origin was established in 1995 in Serbia (Official Gazette of FRY 15/1995 and 35/1995). The harmonized legislation with EU Council Regulation 2081/92, 535/97 and $510 / 2006$, also in the line with the provisions of the World Trade Organization, Madrid and Lisbon treaty arrangement, was adopted in 2010 (Official Gazette of Republic of Serbia 18/10). However, domestic products under PGO and PGI label still can not be found at the market. Additionally, the health claims are not legally treated at all. It does not mean that functional food market is not operative even under unregulated conditions (Stojanović \& Dragutinović-Mitrović, 2011).

\section{THE RESEARCH METHODS}

\subsection{The sampling procedure and research instrument}

Consumer quantitative survey is performed on general population $18+$ in Serbia. The sampling is based on the data from Census and estimated population dynamics. The stratified three-staged random representative sample is applied. The primary sampling units (PSU) are polling station territory; the secondary sampling units (SSU) are households; the tertiary sampling units (TSU) are respondents - the adult member per each chosen household. The total sample was 516, whereas the valid sample for our study was 256 respondents who stated high frequency of traditional or functional food consumption.

The instrument used in this survey was a structured questionnaire consisting of several separate sections, including motivation toward food in general (Food Choice Questionnaire - FCQ), some specific questions about traditional and functional food and consumer's socio-economic and demographic characteristics. Specific questions refer to consumer understanding of traditional food as well as to consumer information and scepticism. As the concept of functional food is a new on the emerging Serbian market, the respondents were previously advised on what was typically assumed under this term. Also, 


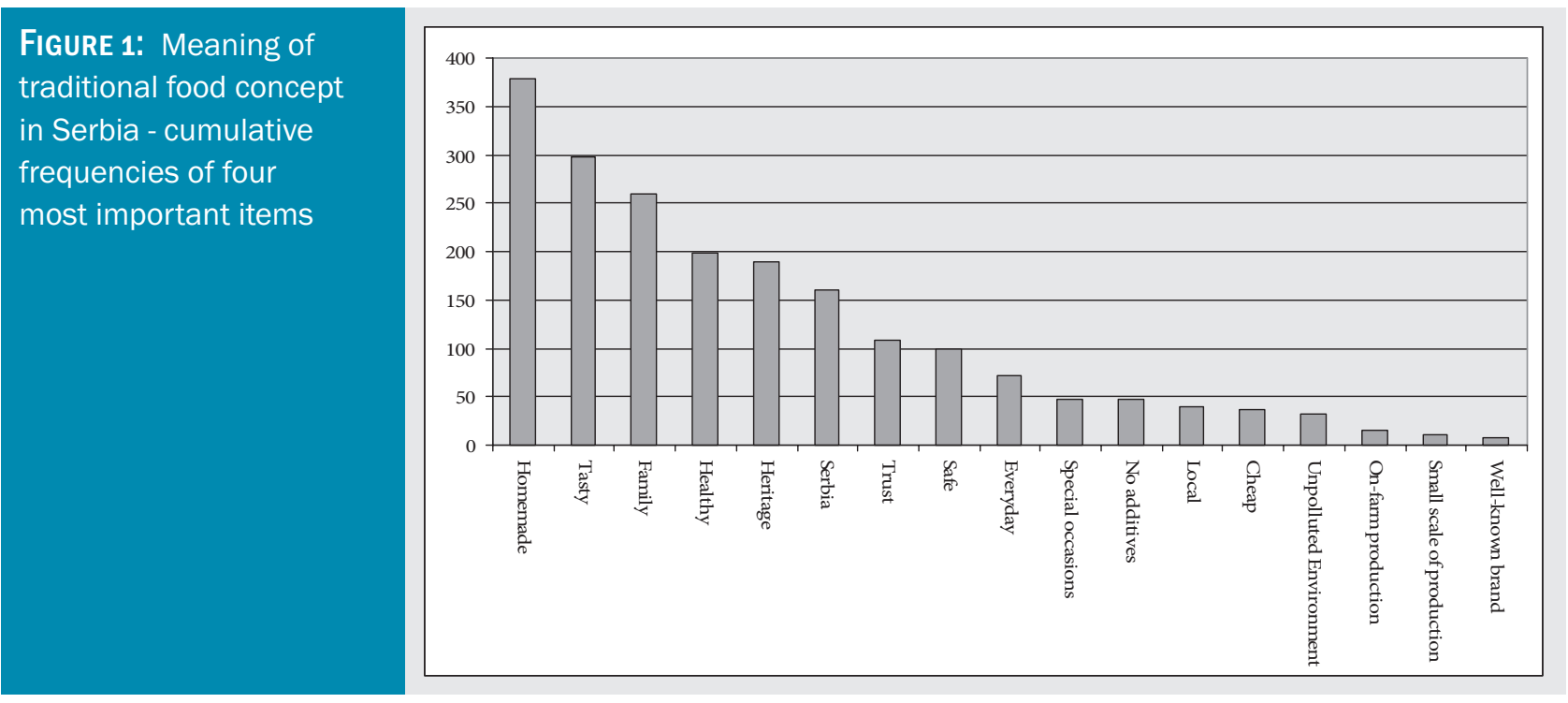

several examples were presented before respondents were asked to complete the survey. Consumers' socioeconomic and demographic characteristics relevant for this study includes their gender and age, level of education, number of household members, type of settlement (rural/urban), employment, height and weight - body mass index (BMI), as well as their selfassessed economic and health status. The dependent variable was self-reported frequency of consumption of the studied categories of food.

\subsection{The methods applied and research questions}

Based on reported frequency of consumption all surveyed respondents were classified. The first group consists of heavy traditional food consumers who simultaneously reported lower level of functional food consumption $\left(\mathrm{N}_{\mathrm{T}}=196\right)$. The second group comprises of heavy functional food consumers with lower level of traditional food consumption $\left(\mathrm{N}_{\mathrm{F}}=60\right)$. A descriptive statistical analysis is conducted aiming at investigating all statistically significant differences between both the heavy traditional and functional consumers' profiles. The differences between the two groups related to a number of socio-economic and demographic variables were measured by parametric (One-Way ANOVA) or non-parametric (Chi Square) statistical tests.

The overall research addresses following question: does tradition keep dominance over new trends in food consumption? In other words, the aim is to investigate weather significant differences between two groups of consumers in Serbia exist regarding their main socioeconomic and demographic characteristics. Profiling two consumer groups (heavy traditional and heavy functional consumers) can improve understanding of contemporary food consumption patterns and their possible dynamics in the future.

\section{RESULTS AND DISCUSSION}

\subsection{Meaning of traditional and functional food concepts}

The results show that heavy traditional food consumers' dominate 'over heavy functional food consumers' group in Serbia. Almost 50\% of all respondents belong to the 'heavy traditional food consumers' group. Every fifth respondent reports the "high functional food consumption'.

The meaning of 'functional food was presented to the respondents before administrating the questionnaire section regarding this food type. Such approach is appropriate because functional food consumption is still in its infancy. Previous studies identified that consumers are not familiar with the term "functional food" or related concepts (e.g. health claims) (. Therefore, our respondents were adviced aobut functional food by explicite explanation of health claims. The following formulation was used: "Health claims that we see on product packages are claims that link a nutrient to a normal functioning of the body or a specific disease. An example of a health claim - High in calcium, Calcium helps build strong bones. Adequate calcium throughout life, as part of well-balanced diet, may reduce risk of the osteoporosis". It generaly refers to milk products available at the market. 


\section{marketing}

TABLE 1: Heavy traditional vs. functional food consumers profile in Serbia, 2010

\begin{tabular}{|c|c|c|c|c|}
\hline Variables & Definition & $\begin{array}{c}\text { Heavy } \\
\text { traditional food } \\
\text { consumers }\end{array}$ & $\begin{array}{c}\text { Heavy } \\
\text { functional food } \\
\text { consumers }\end{array}$ & Statistical tests \\
\hline & & \multicolumn{2}{|c|}{ Mean (standard deviation) } & One-way ANOVA \\
\hline Age & In years & $\begin{array}{c}49.32 \\
(17.376)\end{array}$ & $\begin{array}{c}43.70 \\
(18.052)\end{array}$ & $\mathrm{F}=4.886 * *$ \\
\hline Household members & Total number & $\begin{array}{c}3.33 \\
(1.797)\end{array}$ & $\begin{array}{c}3.05 \\
(1.682)\end{array}$ & $F=1.162$ \\
\hline $\begin{array}{l}\text { Self-assessed } \\
\text { economic status }\end{array}$ & $\begin{array}{l}5 \text { point scale } \\
\text { (1-min, 5-max) }\end{array}$ & $\begin{array}{l}3.02 \\
(0.847)\end{array}$ & $\begin{array}{c}3.13 \\
(0.947)\end{array}$ & $F=0.772$ \\
\hline $\begin{array}{l}\text { Self-assessed health } \\
\text { status }\end{array}$ & $\begin{array}{l}5 \text { point scale } \\
(1-\min , 5-\max )\end{array}$ & $\begin{array}{c}3.68 \\
\text { (sd.0.994) }\end{array}$ & $\begin{array}{c}3.77 \\
\text { (sd.0.927) }\end{array}$ & $F=0.372$ \\
\hline Body mass index (BMI) & $\begin{array}{l}\text { Counted based on stated } \\
\text { weight and height }\end{array}$ & $\begin{array}{l}24.188 \\
(3.8115)\end{array}$ & $\begin{array}{l}23.948 \\
(3.5811)\end{array}$ & $F=4.933$ \\
\hline $\begin{array}{l}\text { Social influences } \\
\text { functional food }\end{array}$ & $\begin{array}{l}5 \text { point scale } \\
\text { (1-min, 5-max) }\end{array}$ & $\begin{array}{c}3.17 \\
(0.943)\end{array}$ & $\begin{array}{c}3.95 \\
(0.775)\end{array}$ & $F=4.972$ \\
\hline \multirow[t]{2}{*}{$\begin{array}{l}\text { Social influences } \\
\text { traditional food }\end{array}$} & $\begin{array}{l}5 \text { point scale } \\
(1-\text { min, } 5 \text {-max })\end{array}$ & $\begin{array}{c}4.42 \\
(0.829)\end{array}$ & $\begin{array}{c}4.15 \\
(0.840)\end{array}$ & $\mathrm{F}=33.580 * * *$ \\
\hline & & \multicolumn{2}{|c|}{ Frequencies (share) } & Parson Chi-Square \\
\hline \multirow{2}{*}{ Gender } & $0=$ male & $\begin{array}{c}84 \\
(42.86 \%)\end{array}$ & $\begin{array}{c}18 \\
(30.00 \%)\end{array}$ & $\begin{array}{c}\text { Chi-Square } \\
3.168^{*}\end{array}$ \\
\hline & $1=$ female & $\begin{array}{c}196 \\
(57.14 \%)\end{array}$ & $\begin{array}{c}42 \\
(70.00 \%)\end{array}$ & \\
\hline \multirow[b]{2}{*}{ Education } & $\begin{array}{l}0=\text { uneducated (primary } \\
\text { school or less) }\end{array}$ & $\begin{array}{c}57 \\
(29.1 \%)\end{array}$ & $\begin{array}{c}9 \\
(15.0 \%)\end{array}$ & $\begin{array}{c}\text { Chi-Square } \\
4.761^{* *}\end{array}$ \\
\hline & $\begin{array}{l}1 \text { = educated (secondary } \\
\text { school/college or university) }\end{array}$ & $\begin{array}{c}139 \\
(70.9 \%)\end{array}$ & $\begin{array}{c}51 \\
(85.0 \%)\end{array}$ & \\
\hline \multirow[t]{2}{*}{ Type of settlement } & $0=$ urban & $\begin{array}{c}100 \\
(51.02 \%)\end{array}$ & $\begin{array}{c}46 \\
(76.67 \%)\end{array}$ & $\begin{array}{l}\text { Chi-Square } \\
0.154\end{array}$ \\
\hline & $1=$ rural & $\begin{array}{c}96 \\
(48.98 \%)\end{array}$ & $\begin{array}{c}14 \\
(23.33 \%)\end{array}$ & \\
\hline \multirow{2}{*}{ Employment } & $0=$ employed & $\begin{array}{c}112 \\
(57.1 \%)\end{array}$ & $\begin{array}{c}36 \\
(60.0 \%)\end{array}$ & $\begin{array}{l}\text { Chi-Square } \\
12.330 * * *\end{array}$ \\
\hline & 1 = unemployed & $\begin{array}{c}84 \\
(42.9 \%)\end{array}$ & $\begin{array}{c}24 \\
(40.0 \%)\end{array}$ & \\
\hline
\end{tabular}

Significant at $10 \%$ significant level. ${ }^{* *}$ Significant at $5 \%$ significant level. ${ }^{* \star}$ Significant at $1 \%$ significant level

However, before any explanation given to the differences in reported frequencies of consumption, it is important to find out what consumers consider under the term "traditional food" in Serbia. Consumer perception of term "traditional food" was tested by letting respondent to choose four out of 17 items that best describe concept (heritage, unpolluted environment, family, Serbia, local, special occasions, homemade, trust, everyday, small scale of production, tasty, healthy, safe, on-farm production, no additives, wellknown brand and cheap). Mesured by cumulative frequencies of four most important items, consumers consider traditional food dominantely as ,home-ma- de', ,tasty', ,family' and ,healthy' (Figure 1). However, the absolutely most important items are ,heritage' and ,family. These itams are chosen as the first association on traditional food by more than $2 / 3$ of all respondents. Contrary, the very low attention is payed to ethical concerns - ,small-scale, ,on-farm production, ,unpolluted environment, and ,local'. According to consumers' perception, it is obvious that "traditional food" in Serbia is perceived as home-made, tasty, healthy and with long tradition produced food.

In order to find out differences between heavy traditional and functional consumers in Serbia both $\mathrm{N}_{\mathrm{T}}$ and $\mathrm{N}_{\mathrm{F}}$ are reduced. Consumers who simultaneously 
stated high consumption of both foods are extracted. Consequently, the relevant sample consists of consumers who stated higher consumption of one food group than in another - e.g. the heavy traditional food profile represent consumers who reported higher traditional food consumption and simultaneously lower functional food consumption, and the heavy functional food group visa versa. The next section explains significant differences between 'heavy consumers' groups regarding their socio-economic and demographic characteristics.

\subsection{Traditional versus functional food in Serbia - which differences between consumers' profiles?}

'Heavy traditional vs. functional food consumers' profiles are described by socio-economic and demographic variables (Table 1). No differences were found regarding household numbers, type of settlement, self-assessed economic and health statuses, BMI and social influences toward functional food consumption. Differences were found in age, gender, education, employment and social influences toward traditional food consumption.

Differences in employment and social influences toward traditional food consumption are found at $1 \%$ significant level. Heavy consumers of traditional food are more unemployed than heavy functional food consumers. Due to clasification, the unemployment in our case also signifies that people are retired, and that is also linked to their age. Pensioners are more represented in the sample of heavy traditional than functional food consumer group in Serbia (32.33\% and $25 \%$ respectively). However, it is equally important to emphasize the structure of unemployed heavy functional food group. It consists significantly more of pupils and students (11.66\%) compared with the structure of heavy traditional food consumer group (pupils and students constitute only 3.53\% of this group). The analysis also shows stronger influence of peers among heavy traditional food consumers in Serbia.

Differences in education and age between two heavy consumer groups exist at 5\% significant level. In comparison with traditional food consumers, functional food consumers in Serbia are higher educated and younger on average. Uneducated (with primary school or less) are more frequently present in heavy traditional food consumers group. Additionally, this group is slightly less than 50 years old on average. An average functional food consumer is around six years younger than traditional one. In the group of educated heavy functional food consumers the college or university degree of education are more frequently present.

Finally, difference at $10 \%$ significant level is noticed in gender. Female respondents are more frequently represented in the heavy functional consumers group, while in the heavy traditional consumers group male respondents are slightly more represented.

The consumer profiles are summarized in Table 2. The explanation of the consumer profiles is additionally confirmed by the focus groups discussions (FGD) conducted prior to quantitative consumer survey in Serbia. Two FGD were conducted with the aim to found out broad context of consumers perceptions of traditional food in Serbia. FGD were conducted in the capital city and in the South-East Serbia during spring in 2010 (Stojanović, Ognjanov \& Filipović, 2010).

For majority of the consumers, traditional food is healthy food (close to organic), and this can lead to the fulfillment of their need of healthy food, being reluctant to consume «industrial» functional food. Additionally, agricultural households are more represented in the heavy traditional food consumers group (their presence is almost $10 \%$ higher than in total population). They have producing home-made traditional products based on family tradition, without additional artificial components. Consequently, share

TABLE 2: Consumer profiles - the characteristics that make differences between heavy traditional and functional consumer groups in Serbia, 2010.

\begin{tabular}{ll} 
Heavy traditional food consumer (HTFC) & Heavy functional food consumer (HFFC) \\
\hline More exposed to peers regarding TFP & Less exposed to peers regarding TFP \\
\hline Unemployed* & Employed \\
Less educated & More educated \\
Older on average than HFFC & Younger on average than HTFC \\
More frequently male & More frequently female
\end{tabular}

\footnotetext{
* Linked with age because the retired people are considered as unemployed.
} 
of these products in overall diet is significant. This result can be placed in parallel to the results of the qualitative survey on functional food. Two FGD (Mothers of children under 15 and 50+ respondents) were conducted during winter in 2009/2010 in the capital city. Consumers are more skeptical toward novel/functional food (Stojanović et al, 2010). Influence of consumers' skepticism on functional food consumption is also confirmed by other studies (Gray, 2002; Niva and Makela 2005; Saaksjrvia et al., 2009).

Additionally, consumer trust declines to some extent with age (Poppe and Kjaernes, 2003) which might have a specific influence on consumers' attitudes toward functional food in our case. However, having in mind the specific findings in Serbia, industrial products and the addition of chemical, artificial contents may provoke these cancers. Earlier findings suggest strong contradiction between the ideal of 'natural' food and 'techno-food' (Stewart-Knox and Mitchell, 2003). Consumers in Serbia insist of products naturalness and pay more attention to home made products or, at least, to shorter food distribution channel.

\section{CONCLUSION AND SUGGESTIONS FOR FURTHER RESEARCH}

The findings presented here are the first results obtained regarding main differences between traditional and functional food consumers' profiles in Serbia. For the time being, traditional food consumers still dominate over novel (functional) food consumers. However, the meaning of traditional food perceived by consumers in Serbia is highly debatable. It refers strongly to the concept of 'home-made' food which includes self-consumption of traditional products (Hamermesh, 2007). It might indicate lower potentials for regional food concept promotion in the country. The concept of regional food has gained in importance in the EU lately (Loureiro and McKluskey, 2000). Our study confirms that the traditional food in Serbia is obviously used as a term for low marketed goods home-produced by traditional recipes. It might be considered as an important restriction for further development of the PGO and PGI scheme in Serbia. The further research can contribute explanation of different meanings of term "traditional food" for different segments of consumers in Serbia. Detailed profiling of traditional food consumers could facilitate improvement of European regional concept of traditional food in our practice.

Due to high share of elderly people in Serbia, tradition still keeps dominance over new trends in food consumption (Stojiljković, 2011). Heavy traditional food consumers are older on average, less educated and more unemployed because a part of them are retired. Additionally they are more influenced by peers and that might indicate high social interferences. The heritage still strongly drives the food consumption toward traditional products prepared at home. However, younger and higher educated heavy functional food consumers indicate higher potentials for the functional food consumption in the future. It is also important to emphasize the role of the female food shoppers. They take care over children and family food consumption. The more represented females in the functional food consumers group can influence changing of diet pattern toward generally healthier food consumption.

Finally, the diet-related diseases are seen as one of the crucial problems of contemporary society. Both developed and developing countries struggles against the increase of certain diet related diseases (diseases related to malnutrition and/or obesity). The public health policy actions toward healthier diet and lifestyle could faster new trends in food consumption in Serbia. At the same time, there is a need to set-up and implement at least equivalent legislation of food labelling related to health claims as it exists in Europe. The importance of this legal framework has been highlighted and deeper discussed by Stojanović and Dragutinović-Mitrović (2011). Regarding consumer scepticism and information, legislation and control system are of crucial importance. Generally, an appropriate public health policy could address this issue in providing specific group of consumers with information about the benefits of taking care of their diet. The dissemination of recommendations about the importance of a balanced diet should take place in some appropriate media for broader consumers groups. It includes education on traditional food - its benefits and relevance for contemporary diet, as well as about functional food and the novel approach related to diet-health or diet-diseases relationship. 


\section{References}

1. Amblard C., Prugnard E. and Giraud G. (2011), D8.1 - Consumers attitudes, expectations and behaviours towards traditional food, FP7 Focus-Balkans project document, www.focus-balkans.org, accessed 07.02.2012.

2. Christidis N, Tsoulfa G, Varagunam M. and Babatzimopoulou M. (2011), A cross sectional study of consumer awareness of functional foods in Thessaloniki, Greece. Nutrition \& Food Science 41:165-174.

3. De Jong, N., Ocke, M.C., Branderhorst, H.A.C. and Friele, R. (2003), Demographic and lifestyle characteristics of functional food consumers and dietary supplement users. British Journal of Nutrition, 89, pp. 273-281.

4. Dimitrijevic-Brankovic I.S., Baras J.K. and Bojovic J. (2002), Značaj i mogućnosti proizvodnje funkcionalne hrane, (engl. Importance and possibilities for the functional food production), Hemijska industrija, vol. 56, (3) pp. 113-122.

5. Diplock, A.T., Agget, P.J., Ashwell, M., Bornet, F., Fern, E.B. and Roberfroid, M.B. (1999), Scientific concepts of functional foods in Europe: consensus document. British Journal of Nutrition, 81, pp. 1-27.

6. Gray, J. (2002), Consumer perception of the functional dairy food market in Northern Ireland, International Journal of Consumer Studies, 26, (2) pp. 154-158.

7. Hamermesh, D.S. (2007), Time to Eat: Household Production under Increasing Income Inequality, American Journal of Agricultural Economics, 89, (4) pp. 852-863.

8. Loureiro, M.L. and, McCluskey, J. (2000), Assessing consumer Response to Protected Geographical Identification Labeling, Agribusiness, Vol. 16, , No. 3, pp. 309-320.

9. Miletić I., Šobajić S. and Djordjević B. (2008), Funkcionalna hrana - uloga u unapređenju zdravlja, (engl. Functional food - the health improvement role), Journal of Medical Biochemistry, vol. 27, (3) pp. 367-370.

10. Milošević, J., Žeželj, I., Gorton, M. and Barjolle, D. (2012), Understanding of motives of food choice in Western Balkan Countries, Apettite, Vol. 58, Issue 1, pp. 205-214.

11. Niva M. and Makela J. (2005), Finns and functional foods: socio-demographics, health efforts, notions of technology and the acceptability of health-promoting foods, Journal of Consumer Studies, pp. 35-45.

12. Parlement Européen, Direction generale des politiques internes de l'Union, Département thématique b: Politiques structurelles et de cohésion, agriculture et développement rural (2011), „Petits agriculteurs et marches locaux dans le contexte de la politique Europenne de la qualite“, ref. IP/B/AGRI/ IC/2011_020

13. Poppe, C. and Kjaernes, U. (2003), Trust in Food in Europe. A Comparative Analysis. National Institute for Consumer Research, Oslo. [WWW ducument]. URL http://www.trustinfood.org/SEARCH/BASIS/ tif0/all/publics/DDD/24.pdf.

14. Ricketts, H.J., Ilbery, B. and, Kneafsey, M. (2006), Distribution of Local Food Activity in England and Wales: An Index of Food Relocalization, Regional Studies, 40, (3), 289-301.

15. Ristić G.N. (2003), Funkcionalna hrana - hrana za XXI vek, (engl. Functional food - food for $21^{\text {st }}$ century), Mlekarstvo, vol. 2, (14) pp. 428-433.

16. Saaksjarvia, M., Holmlundb, M. and Tanskanenb, N. (2009), Consumer knowledge of functional foods, The International Review of Retail, Distribution and Consumer Research, Vol. 19, No. 2, pp. 135-156.

17. Sijtsema, S.J., Backus, G.B.C., Linnemann, A.R., and Joungen, W.M.F. (2003), Linking Consumers' Perception of Health-promoting Food Attributes to Tangible Product Characteristics, The EAAE Seminar Consumer Perceptions of Healthiness of Food and Consumer Acceptance of New Functional Foods, Middelfart, Denmark.

18. Šobajić S. (2002), Funkcionalna hrana u prevenciji bolesti i terapiji, (engl. Functional food in the prevention of diseases and treatment), Arhiv za farmaciju, vol. 52-3, pp. 369-375.

19. Stanković I.M., Djordjević B.I. (2002), Funkcionalna i nekonvencionalna hrana - zakonska regulativa, (English - Functional and Unconventional Food Legislative), Hrana i ishrana, vol. 43, (1-2) pp. 60-62.

20. Stewart-Knox, B. and Mitchell, P. (2003), What separates the winner from the losers in new food product development? Food Science and Technology, 14 , pp. 58-64.

21. Stojanović Ž. and Dragutinović-Mitrović R. (2012), Serbian Functional Food Market: Does Regulation make differences?, print in ed. Boričić B. \& Jovičić M., Factor Markets and the Effects of the World Crisis, CIDEF, Belgrade, Volume II, pp. 229-245.

22. Stojanović, Ž., Ognjanov, G. and Filipović, J. (2010), Traditional food and its Implications for Development of Rural Tourism in Serbia, Ekonomika poljoprivrede, SI (2), pp. 352-358.

23. Stojanović, Ž., Ognjanov, G., and DragutinivićMitrović, R. (2010), Health Claimed Products and Consumer Attitudes in Balkan Countries, Annual Meeting of European Association of Animal Production, August 23-27., 2010, Book of Abstracts, EAAP, p. 332. 
24. Stojanović, Ž., Zaouche-Laniau, M., Barjolle, D. and Esteve, M. (2010), D6.1 - Consumer motivations and behaviours for products with nutrition and health claims, FP7 Focus-Balkans project document, www. focus-balkans.org, accessed 07.02.2012.

25. Stojilković, J. (2011), Growing Number of Pensioners and Population Aging in Serbia, Journal of the Geographical Institute "Jovan Cvijić", 61(2), pp. 69-84.

26. The Regulation on Geographical Indications of Origin (2010), Official Gazette of Republic of Serbia 18/10.
27. Vogt, R.A. and Kaiser, L.L. (2008), Still a time to act: A review of institutional marketing of regionally-grown food, Agriculture and Human Values, 25, pp.241-255.

28. Wilson, N. and, Fearne, A. (2000), A Link between Modernity and Tradition - the Case of Several Regional Food Products, in Economie et Sociologie Rurales, Actes et Communications, INRA, 17, (2) pp. 277-294.

\section{Rezime}

\section{Socioekonomski i demografski profil potrošača tradicionalne i funkcionalne hrane u Srbiji}

Žaklina Stojanović, Dominique Barjolle

Kvantitativno istraživanje potrošača izvršeno je na opštoj populaciji 18+ krajem septembra - početkom oktobra 2010. godine u Srbiji. Instrument koji je korišćen u istraživanju je strukturirani upitnik. Reprezentativni stratifikovani troetapni slučajni uzorak je primenjen $(\mathrm{N}=516)$. $\mathrm{Na}$ osnovu prijavljene učestalosti konzumiranja identifikovane su dve grupe potrošača: konzervativni potrošači $(\mathrm{NT}=196)$ i inovatori $(\mathrm{NF}=60)$. Deskriptivna statistička analiza je sprovedena sa ciljem da se istraže sve statistički značajne razlike između dve grupe profila potrošača. U našem uzorku tzv. konzervativni potrošači dominiraju nad velikim potrošačima funkcionalne hrane. Veliki konzumenti tradicionalne hrane su u proseku stariji, među njima su brojno zastupljeniji nezaposleni (penzioneri se u našem slučaju ubrajaju u ovu kategoriju) i više su izloženi uticajima socijalne sredine. „Tradicionalna hrana“ se u Srbiji doživljava kao domaća, ukusna, zdrava i kao hrana sa istorijskim nasleđem. Razlike u starosti i obrazovanju između dve grupe potrošača ukazuju na moguću tranziciju u pravcu značajnije konzumacije funkcionalne hrane. Ključne reči: tradicionalna hrana, funkcionalna hrana, potrošnja, profil ptorošača.

Kontakt:

Dr Žaklina Stojanović, vanredni profesor Ekonomski fakultet, Univerzitet u Beogradu e-mail: zaklina@ekof.bg.ac.rs

Dr. Dominique Barjolle, Institute for Environmental Decisions, ETHZ, Zürich, e-mail: barjolle@ethz.ch 